\title{
Market orientation and corporate social responsibility: towards an integrated conceptual framework
}

\author{
Mahmoud Abdulai Mahmoud ${ }^{1 *}$, Charles Blankson² and Robert E. Hinson ${ }^{1}$
}

\begin{abstract}
The aim of this study is to develop a comprehensive framework and propositions showing the integration of market orientation (MO) as an economic-oriented strategy and corporate social responsibility (CSR), as a sociallyoriented strategy for business performance (BP). A review of literature on the three constructs of MO, CSR and BP facilitated the development of the framework and a number of research propositions. An integrated conceptual framework of economic and social strategies is constructed based on prior conceptualisation of MO and CSR. In total, twenty-six (26) propositions are developed based on the integrated conceptual framework. An empirical examination of the model will clarify further, relations among the variables and then authenticate the developed model and propositions. The study provides practitioners with a framework and the accompanying propositions for decision making with respect to their strategic choices and performance. The conceptual framework and the proposition developed when implemented are expected to enhance both the firm and customer value which has a wider implication for the society. The novelty in this research is the common antecedents of both MO and CSR. This research augments the few studies on the integration of MO and CSR.
\end{abstract}

Keywords: Market orientation, Economic strategy, Corporate social responsibility, Social strategy, Business performance, Framework, Propositions

\section{Introduction}

A growing number of scholars and practitioners are calling for attention to be given to the integration of market orientation (MO) and corporate social responsibility (CSR) for competitiveness (Brik et al. 2011; Mitchell et al. 2010; Qu 2009). Despite the prominence of MO and CSR, previous scholarships on the two constructs have focused on the individual strategic constructs and their impact on organisational performance to the neglect of their integration (Mitchell et al. 2010; Grinstein 2008). Thus, Grinsatein (2008) advised that research on MO should shift its focus. According to Grinstein (2008), researchers should move from the study of the direct effect of $\mathrm{MO}$ on business performance to the study of the various combinations of strategic orientations that firms can pursue in different situations. Researchers are

\footnotetext{
*Correspondence: mamahmoud@ug.edu.gh

'Department of Marketing and Entrepreneurship, University of Ghana

Business School, University of Ghana, Accra, Ghana

Full list of author information is available at the end of the article
}

encouraged to study how the more successful marketoriented firms balance between MO and other strategic orientations (Grinstein 2008; Mitchell et al. 2010). A number of scholars have responded to this call in the extant MO literature (Yan et al. 2017; Felix 2015). Relatively, some research works have been done on the integration of MO - CSR - performance relationship but more research is required to highlight the phenomenon (Brik et al. 2011; Qu 2009).

Scholars have suggested the benefits of integrating $\mathrm{MO}$ as an economic strategy with CSR as a social strategy (Mitchell et al. 2010; Mohr and Sarin 2009). For instance, it is argued that the pursuit of both economic and social strategies simultaneously would not be harmful to the operations of a firm (Mohr and Sarin 2009). On the bases of the above argument, this study is set out to develop a comprehensive conceptual framework and propositions that guides the integration of $\mathrm{MO}$ and CSR for BP. In this regard, the key question that needs to be answered is whether there are sufficient frameworks that 
project the integration of $\mathrm{MO}$ as an economic strategy and CSR as a social strategy leading to business performance in extant marketing and management literature?

The paper contributes to marketing theory in three ways. First, it proposes a comprehensive business framework integrating $\mathrm{MO}$ and CSR for BP. Limited frameworks exist on the integration of MO, CSR and BP (Brik et al. 2011; Morgan et al. 2009; Grinstein 2008; Maignan and Ferrell 2004; Maignan et al. 1999; Morgan and Strong 1998). Second, we propose common determinants of MO and CSR, which to the best of the researchers' knowledge, have never been proposed in the extant marketing literature. To buttress this position, reference is made to Kuada and Hinson's (2012) argument that the antecedents to CSR exert different degrees of influence on the CSR practices of firms in different parts of the world. They argue further that these antecedents have not been adequately articulated and integrated into the available analytical models.

Third, the conceptual framework and the propositions from the research is significant for management researchers and practitioners. Employing the theorised framework and propositions will allow scholars to offer relevant advice on the likely outcomes of integrating
$\mathrm{MO}$ and CSR across firms of varying backgrounds. The remainder of the paper is presented as follows: the conceptual framework and propositions are discussed next and this is followed by the discussions and implications. The conclusions and directions for future research bring the paper to a close.

\section{Literature review and conceptual framework}

In the conceptualisation of market orientation (MO) and corporate social responsibility (CSR), researchers often theoretically or empirically investigate their antecedents or predictors and consequences or outcomes (Galbreath 2010; Zebal and Godwin 2011; Kocak et al. 2017). The proposed integrated conceptual framework for this study has five major components (see Fig. 1).

Hult et al. (2005) established the value of the information processing perspective to market orientation. Market orientation is defined as the extent to which a firm engages in information generation, dissemination, and response to market intelligence pertaining to current and future customer needs, competitor strategies and actions, channelling requirements and abilities, and the broader business environment (Morgan et al. 2009). Inspired by the traditional resource-based theory, the literature posits that firms with superior MO achieve

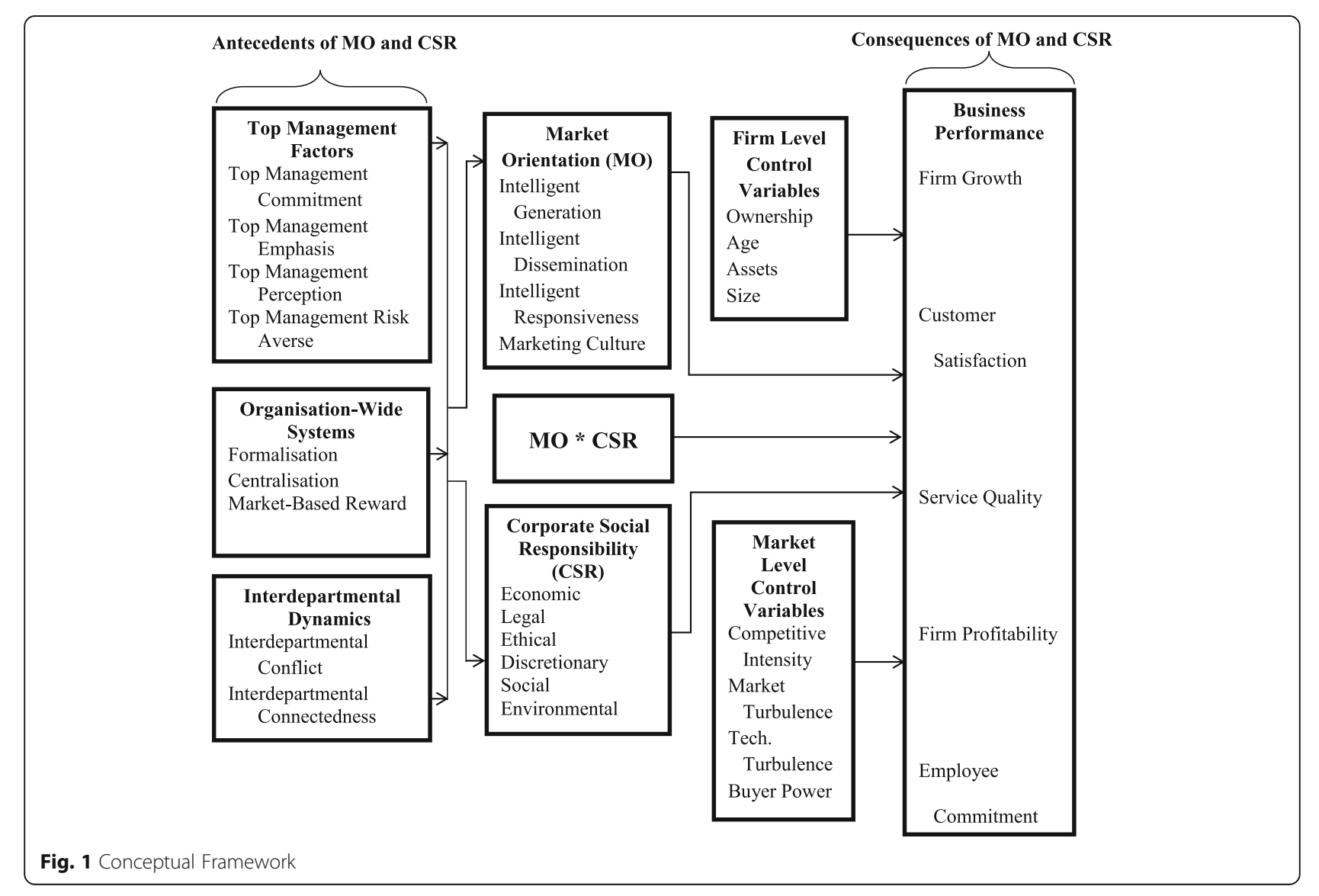


superior business performance because they have a greater understanding of customers (Lafferty and Hult 2001).

There has been a general agreement in the literature on the key components of MO: market intelligence gathering and the synthesis of market information to develop and implement competitive, profitable marketing strategies (Cano et al. 2004; Cervera et al. 2001; Greenley et al. 2005; Kirca et al. 2005; Kohli and Jaworski 1990; Lafferty and Hult 2001). MO should focus on the integration of a firm's capabilities to generate long-term profitability, maintain or increase market share, improve firm competitiveness, ensure organisational responsiveness in providing customer value and satisfaction, and meet strategic corporate targets (Mitchell et al. 2010).

With respect to CSR, Whitehouse (2006) opined that despite several decades of vociferous debate regarding the concept of CSR, it is possible to say, with certainty, that there exists no one universally accepted definition of the term. Lantos (2001) is of the view that the concept of CSR is a fuzzy one with unclear boundaries and debatable legitimacy. While academics continue to debate the content and meaning of CSR, many large companies appear to have found common ground upon which they have constructed elaborate CSR policies and practices (Whitehouse 2006).

Carroll's (1991) classification of CSR was modified to include social and environmental dimensions (Mitchell et al. 2010) to conceptualise corporate social responsibility in this integrated framework. Carroll (1991) provides a clear view of business responsibility and repeats these four dimensions in subsequent articles (Carroll 2000; Schwartz and Carroll 2003) to underscore the importance of this classification in future CSR studies. Hence, the adoption of Carroll's model. Consequently, from the basis of Carroll's (1991) conceptualisation, CSR has been defined by Maignan et al. (1999, p. 459) as "the extent to which businesses meet the economic, legal, ethical and discretionary responsibilities imposed on them by their stakeholders". This definition is in line with the four dimensions of CSR proposed by Carroll (1991), which is still recognised by contemporary researchers (Maignan et al. 1999; Maignan and Ferrell 2004; Pirithiviraj and Kajendra 2010; Galbreath 2010). These six dimensions of CSR adapted for this study are considered appropriate to investigate CSR in order to address the accusation against marketing scholars for their narrow focus on the dimensions of CSR (Maignan and Ferrell 2004; Porter and Kramer 2006).

\section{Propositions}

The three major hierarchical dimensions of top management factors, organisational systems and interdepartmental dynamics proposed by Kohli and Jaworski (1990) and
Jaworski and Kohli (1993), which have been used widely in the market orientation literature, are employed in this study. However, the present study extends strategic marketing knowledge by postulating that these factors are equally determinants of CSR. The proposed integrated conceptual framework suggests the measures can be used to assess the firm's level of MO and CSR activities and initiatives.

\section{Top management factors}

A number of scholars have alluded to the importance of top management in determining an organisation's market orientation and corporate social responsibility (see Kohli and Jaworski 1990; Jaworski and Kohli 1993; Aguinis and Glavas 2012). These scholars assert that with more support from top management, CSR programmes will be given more attention than with less management support (see Aguinis and Glavas 2012). Without support from top management, it will be difficult to formulate and implement market orientation and corporate social responsibility programmes. Top management is a key stakeholder whose level of influence on firms' $\mathrm{MO}$ and CSR initiatives cannot be ignored. Top management support ensures that MO and CSR programmes succeed. Top management demonstration of leadership by example encourages employees to follow suit. If top management is involved in gathering intelligence, disseminating this intelligence and being responsive to the needs of both internal and external demands, other staff members will also be encouraged to do so. Similarly, maximising shareholder wealth, operating within the legal and ethical framework of the firm's environment and also showing concern for the larger society by acting responsibly and donating to charitable institutions demand the support of top management. On the basis of the above arguments, we proposed as follows:

P1: Top management emphasis relate to organisations market orientation and corporate social responsibility.

Top management's risk aversion is another key factor among the antecedents to MO and CSR in the conceptual framework. Top management's willingness to strategically allow new ideas to be experimented will aid the $\mathrm{MO}$ and CSR development process in firms. In the same vein, if top management is always searching for certainty before making decisions, it could stifle MO and CSR initiatives. Intelligence generation, intelligence dissemination and intelligence responsiveness, as well as the marketing culture of an organisation, are all influenced by top management's risk aversion. In more elaborate terms, one can postulate that top management's risk aversion has an influence on the economic, legal, ethical, philanthropic, social and environmental performance of an organisation. Jaworski and Kohli (1993) found a negative association between top management risk aversion and intelligence responsiveness while Avlonitis and 
Gounaris (1999) also found a negative association between top management risk aversion and market orientation. Thus,

P2: Top management risk aversion relate to organisations market orientation and corporate social responsibility.

The conceptual framework further suggests that top management's perception is an integral component among the top management factors which are critical to predicting the level of $\mathrm{MO}$ and CSR. Perceptions have a serious influence on top management actions and reactions towards MO and CSR initiatives. Favourable perceptions of managers towards marketing intelligence generation, dissemination, responsiveness, as well as the beliefs and values in marketing practices could elicit top management support of $\mathrm{MO}$ and CSR practices. Also, top management's favourable perception towards the economic performance of the organisation will encourage them to support MO and CSR activities. This notion is applicable to ethical conduct, legal obligations, social and philanthropic interventions, as well as good environmental activities. Thus,

P3: Top management perception relate to organisations market orientation and corporate social responsibility.

Another major predictor variable in the conceptual framework, that could stimulate an organisation's market orientation and corporate social responsibility is the organisational system. This comprises formalisation, centralisation and market-based reward systems. Earlier studies have found that both centralisation and formalisation are negatively associated with overall market orientation (Jaworski and Kohli 1993; Avlonitis and Gounaris 1999; Harris 2000). On the contrary, a number of studies reported a positive relationship between market orientations; formalisation and centralisation. This suggests that scholars are still in a dilemma as far as the role of formalisation and centralisation in the development of market orientation are concerned. Therefore, the inclusion of these factors in the study's framework is intended to provide further empirical insight into these variables. Inferring from the MO literature, the conceptual framework additionally postulates that the organisational system has an influence in shaping an organisation's CSR activities.

\section{Organisational systems}

Formalisation is the "degree to which rules define roles, authority, relations, communications, norms and sanctions, and procedures" (Kohli and Jaworski 1990, p. 10). Often, it is assumed that bureaucratic tendencies are likely to be associated with arrangements which can impede the development of a market orientation culture in such formalised institutions. A high degree of formalisation can result in low market orientation culture in an organisation, which in turn can impact the organisation's efficiency and effectiveness and hence its business performance. Formalisation affects the development of a market orientation culture (Jaworski and Kohli 1993; Kuada and Buatsi 2005; Zebal and Godwin 2011). Research on the predictors of market orientation so far suggests that formalisation is a barrier to communication and consequently hostile to market-oriented activities (Zebal and Godwin 2011). Formalisation is postulated to impede innovation and timely responses to changing market needs, which are at the core of market orientation (Kohli and Jaworski 1990; Jaworski and Kohli 1993). Kuada and Buatsi (2005) conclude that formalisation has no role in the market orientation model. Jaworski and Kohli (1993) report that contrary to prior hypotheses, formalisation does not appear to be related to market orientation.

P4: Formalisation relate to organisations market orientation and corporate social responsibility.

Centralisation is described as the concentration of power and decision-making in an organisation on top management (Kohli and Jaworski 1990; Jaworski and Kohli 1993). In this sense, employees at the lower levels who are knowledgeable about market requirements are not given the opportunity to act voluntarily without approval from the top management. Thus, generating, dissemination and responsiveness to market intelligence are impeded, resulting in low MO levels in such organisations. Hence, organisational structures of centralisation also affect the development of market orientation. They are negatively and significantly related to market orientation, according to the study of Kuada and Buatsi (2005). Flavián and Lozano (2006), however, could not conclude on the role of centralisation in the development of market-oriented culture.

P5: Centralisation relate to organisations market orientation and corporate social responsibility.

Market-based reward schemes are basically how management and employees are rewarded for their effort in contributing to the attainment of the organisation's goals. Webster (1988) is of the view that the cornerstone of developing a market-driven or customer-oriented business organisation is how management is evaluated and rewarded. Jaworski and Kohli (1993) contend that organisations that reward their management and employees based on certain factors, such as customer satisfaction and building customer relationships, tend to be more marketoriented. Pulendran et al. (2000) support this assertion, and advocate that organisations must use market-based reward schemes to reduce role conflict and ambiguity within their operations. On the basis of the above findings, the inclusion of market-based reward schemes in the conceptual framework to determine market orientation and corporate social 
responsibility is therefore timely and justifiable. Therefore,

P6: Market-based reward system relate to organisations market orientation and corporate social responsibility.

\section{Interdepartmental dynamics}

Interdepartmental dynamism consists of interdepartmental conflict and interdepartmental connectedness, which could either enhance or impede the development of market orientation and corporate social responsibility. Scholars report that the implementation of market orientation is determined by interdepartmental conflict and interdepartmental connectedness (Kohli and Jaworski 1990; Jaworski and Kohli 1993). Empirically, interdepartmental conflict is negatively associated with market orientation (Pulendran et al. 2000). Interdepartmental conflicts create barriers among various departments in an organisation and stifle the flow and the exchange of information. In this regard, suggesting interdepartmental conflict as an antecedent to market orientation and corporate social responsibility in the conceptual framework appears reasonable. Consequently,

P7: Inter-departmental conflict relate to organisations market orientation and corporate social responsibility.

Interdepartmental connectedness is another variable of interdepartmental dynamism which is a key antecedent to market orientation. A number of empirical studies point to the fact that interdepartmental connectedness is significant and positively related to market orientation (Jaworski and Kohli 1993; Harris and Piercy 1999; Pulendran et al. 2000). Due to the role interdepartmental connectedness plays in determining market orientation, it is appropriate to propose that interdepartmental connectedness is a variable influencing the degree of market orientation and corporate social responsibility in the conceptual framework of the study. So,

P8: Inter-departmental connectedness influences organisations market orientation and corporate social responsibility.

\section{Consequences of $\mathrm{MO}$ and CSR}

Business performance was conceptualised using six different measures as shown in the conceptual framework. These are: overall business performance (Harris and Ogbonna 2001; Matsuno et al. 2000; Kwon and $\mathrm{Hu}$ 2000), customer satisfaction (Galbreath 2010), service quality (Galbreath 2010; Agarwal et al. 2003), profitability firm growth (Morgan et al. 2009) and employee commitment (Galbreath 2010; Jaworski and Kohli 1993). Overall, business performance combines all five measures. Scholars have reported positive, negative, significant and non-significant relationships between market orientation and organisational performance in the extant literature (Lukas and Ferrell 2000; Ellis 2006; Kirca et al.
2005; Zhou et al. 2005; Atuahene-Gima 2005; Kyriakopolos and Moorman 2004; Voola and O'Cass 2010). Market orientation is associated with both objective and subjective performance variables. Objective measures include profitability, return on assets and firm growth, whereas subjective measures employed include customer satisfaction, service quality and employee commitment. Market orientation has a positive relationship with overall business performance and it is frequently postulated to improve business performance (Kirca et al. 2005; Zhou et al. 2005).

Narver and Slater (1990) were the first to provide empirical evidence on the link between market orientation and business performance. Subsequently, many studies from developed and developing economy perspectives have examined the relationship between market orientation and business performance (Mahmoud et al. 2010; Opoku and Essien 2011; Mahmoud et al. 2010). Market orientation is, thus, viewed as a source of competitive advantage for an organisation, in that it helps to create superior value for customers (Narver and Slater 1990; Slater and Narver 1994; Slater and Narver 2000). Dwairi et al. (2007) replicated Kohli and Jaworski's (1990), and Jaworski and Kohli's (1993) entire market orientation model in Jordan to investigate MO and business performance. They found that $\mathrm{MO}$ is significantly related to business performance. They report that their findings generally resonate with the results of Jaworski and Kohli (1993) and offer empirical support for the robustness of Kohli and Jaworski (1990) and Jaworski and Kohli's (1993) market orientation model. A replication of Jaworski and Kohli's (1993) model by Kuada and Buatsi (2005) in the Ghanaian context generated similar results. Accordingly,

P9: Market orientation is related to overall business performance.

The business community is increasingly committed to incorporating CSR into strategic and business planning. CSR is not only a prominent research theme, but also it can be found in corporate missions and value statements (Svendsen et al. 2001). CSR is argued to be capable of improving a business' competitive position (Porter and Kramer 2006, 2011) and performance (Prado-Lorenzo et al. 2008; Quazi and Richardson 2012). A mixed result has been presented in the scholarly literature regarding corporate social responsibility and business performance (Peloza 2009; Prado-Lorenzo et al. 2008; Luo and Bhattacharya 2006; Sen and Bhattacharya 2001). Whilst some studies are reporting a positive relationship between firms embarking on corporate social responsibility and business performance (see Peloza 2009; Luo and Bhattacharya 2006), others are reporting a negative relationship (see Peloza 2009). Moreover, some studies are establishing no relationship between corporate social responsibility and business performance (see Peloza 2009). In a review of 128 
studies that explored the CSR-organisational performance relationship; Peloza (2009) reported that 59\% found a positive relationship, $27 \%$ indicated a mixed or neutral relationship, and $14 \%$ found a negative relationship. A variety of performance variables have been associated with corporate social responsibility in the extant literature, and these include customer satisfaction, service quality, growth, employee commitment, profitability and overall business performance (Weber 2008; Lee et al. 2011; Luo and Bhattacharya 2006; Backhaus et al. 2002; Brammer and Millington 2005; Peterson 2004).

Lee (2008) posit that the development of CSR theories suggests that there is a tighter linkage between CSR and firm business performance. The emphasis of CSR theories has shifted away from an ethics orientation to a performance orientation. In addition, the level of analysis has moved away from a macro-social level to an organisational level, where the effects of CSR on firm financial performance are closely scrutinized. Vogel (2005) upholds that the close investigation of the relationship between CSR initiatives and firm financial performance is a characteristic of the 'new world of CSR'. He argues that 'old style' CSR of the 1960s and 1970s was motivated by social considerations. Economic considerations were not among the motives for CSR: 'while there was substantial peer pressure among corporations to become more philanthropic, no one claimed that such firms were likely to be more profitable than their less generous competitors'; in contrast, the essence of the 'new world of CSR' is 'doing good to do well' (Vogel 2005, pp. 2021). Therefore, we propose that,

P10: Corporate social responsibility is related to overall business performance.

The integration of MO and CSR on organisational performance is operationalised in the framework by integrating market orientation and corporate social responsibility. This is expected to result in synergy, and thus translate into superior organisational performance (Narver and Slater 1990; Maignan et al. 1999; Qu 2009; Pirithiviraj and Kajendra 2010; Brik et al. 2011; Arshad et al. 2012). The integration of MO and CSR as a competitive strategic tool is key to this study. An emerging logic in marketing is that multiple approaches to strategy from both social and economic perspective is key to guarantee certain level of business performance (Mahmoud 2016). Scholars' attention has been drawn to the fact that market orientation needs to be incorporated as a bundle into other strategic actions to achieve effective and efficient performance (Cano et al. 2004; Qu 2009; Brik et al. 2011; Hakala 2011; Mahmoud 2016). Mitchell et al. (2010) advocated for the incorporation of macro marketing variables such as corporate social responsibility, ecological and environmental issues as additional variables into future market orientation studies. Accordingly, we argue in this study that:
P11: Integration of MO and CSR is related to overall business performance.

\section{MO, CSR and customer satisfaction}

In this conceptualisation, customer satisfaction generally means a service firm's capability to deliver products and services within the customer's zone of tolerance (Zebal and Godwin 2011); that is, not below the customer's expectations and not above the customer's ideal expectation (Zeithaml 2000). There are many items that must be incorporated into generating the desired customer satisfaction relative to the competition. This makes it challenging to use a single issue to constitute customer satisfaction. Moreover, customers differ in the value they attach to each of these elements. Customer satisfaction means that relative to other competitors, the firm has more loyal customers. In this paper, it is also apparent that such firms often receive complimentary phone calls/letters from their customers (Zeithaml 2000). In addition, regarding customer satisfaction, the paper also recognised the fact that the firm's trade partners always give positive testimonies to the quality of service rendered to them. If complaints are minimal, if not absent altogether, it is considered a sign of customer satisfaction in this study (Hinson 2006). It also means the service firm is able to generate new customers on a regular basis without difficulty and that existing customers are happy with the services and prices.

Customer satisfaction has long been considered a resource that generates competitive advantage in the marketplace and thereby triggers superior financial performance for a firm relative to its competitors (Hunt and Morgan 1995). One of the most important indicators of the strength of a firm's customer relationship is customer satisfaction (Anderson et al. 2004). Fornell (1992) has postulated that satisfied customers can be viewed as economic assets that yield future cash flows for organisations. Customer satisfaction affects the level, timing, and risk of a firm's future net cash flows. It triggers positive outcomes such as customer loyalty, customer retention, cross-buying activity, price tolerance, word of mouth, and recommendation behaviour (Anderson et al. 2004; Fornell et al. 2006; Gruca and Rego 2005; Luo 2007; Luo and Homburg 2007; Luo et al. 2010), which in turn enhance future cash flows. The key issue is that market-oriented firms or organisations respond to customer needs and preferences better than less market-oriented firms, hence, they are in a position to satisfy customers (Kohli and Jaworski 1990; Jaworski and Kohli 1993; Slater and Narver 2000). Scholars opine that the consequence of market orientation is customer satisfaction, which increases repeat purchases and draws new customers to the business (Kohli and Jaworski 1990; Singh and Ranchhod 2004). Slater and Narver (2000) are 
of the view that becoming and remaining market-oriented is essential for a company's success. Market orientation is such that it creates loyal customers, who will not only keep coming back to the organisation, but will also tell others about the organisation (Kohli and Jaworski 1990). Hence,

P12: Market orientation is related to customer satisfaction.

The role of corporate social responsibility in determining the level of customer satisfaction has received little attention, despite the acknowledged importance of customer satisfaction in the marketing literature (McDonald and Rundle-Thiele 2008). The relationship between corporate social responsibility and customer satisfaction is not always straightforward (Luo and Bhattacharya 2006). CSR is found to be associated with customer satisfaction in a recent study in the banking sector (Senthikumar et al. 2011). Some scholars are of the view that CSR only results in customer satisfaction when the CSR initiatives and activities have a direct benefit for the customer group concerned (see McDonald and Hung Lai 2011).

Luo and Bhattacharya (2006) discovered that in firms that are less innovative in nature, CSR may decrease customer satisfaction levels and ultimately reduce the firm's financial returns. In this case, it implies that firms do not always benefit from CSR actions and that "less innovative firms may be better off financially avoiding CSR actions" (Luo and Bhattacharya 2006, p. 16). Sen and Bhattacharya (2001) report that CSR initiatives can under certain circumstances decrease consumer's intention to buy a firm's products and/or services. In particular, failing to secure the legitimacy from the target market to operate as a result of firms' CSR initiatives activities can result in a decrease in consumer intention to purchase. This, therefore, makes it imperative for firms to adopt an integrated corporate strategy rather than an individual one.

P13: Corporate social responsibility is related to customer satisfaction.

Galbreath's (2010) empirical study reported that CSR was significantly and positively associated with customer satisfaction. Organisational performance is operationalised in the framework by integrating MO and CSR leading to customer satisfaction. The integration of $\mathrm{MO}$ and CSR as a competitive strategic tool is key to this study. An emerging logic in marketing is that multiple approaches to strategy from both social and economic perspectives is key to guarantee a certain level of business performance (Mahmoud 2016). Scholars' attention has been drawn to the fact that market orientation needs to be incorporated as a bundle into other strategic actions to achieve effective and efficient performance (Cano et al. 2004; Qu 2009; Brik et al. 2011; Hakala 2011; Mahmoud 2016). Mitchell et al. (2010) advocated for the incorporation of macro marketing variables such as corporate social responsibility, ecological and environmental issues as additional variables into future market orientation studies. Accordingly, we argue in this study that:

P14: Integration of MO and CSR is related to customer satisfaction.

\section{MO, CSR and firm growth}

Firm growth in this conceptualisation represents multiple dimensions. Firm growth in this study refers to improvements in: return on investment, profit margin, sales, market share, revenue and financial position relative to competitors. The organisation's ability to recoup its investments or meet its return on investment goals is an indication of growth (Narver and Slater 1990; Morgan et al. 2009). Also, improvement in the organisation's financial position relative to the competitor is associated with the firm's growth. Similarly, an improvement in sales either in quantity or revenue could be regarded as firm growth (Morgan et al. 2009). Improvement in the market share relative to competitors could also be viewed as growth for the firm (Morgan et al. 2009).

Market orientation has a positive link with firm growth. Empirical research has shown that market orientation is related positively to sales growth (Slater and Narver 1994). Service organisations that grow do so because they are good at finding their market niche and understanding market demands, which amount to being market-oriented. Usually, most firms cite the lack of demand as an important impediment to growth. Lack of demand may also be understood as targeting the wrong market, which is to say that consumer research is not guiding the firm's operations. There are several examples of firms that, at least for a period of time, stopped growing because they did not keep up with market orientation activities (Kohli and Jaworski 1990; Narver and Slater 1990). To be more likely to succeed, aspiring growth-oriented firms must appreciate how to adequately identify their market niches and how to exploit them. They also must come to appreciate the importance of putting the customer first and what that implies for their operations.

P15: Market orientation is related to a firm growth.

Even in difficult times or slow periods of growth, CSR is still recommended as a strategic tool for firms' growth. This is even more important for developing economies, especially in sub-Saharan Africa where the poverty level is high (Hinson and Ndhlovu 2011). In such economies, organisations are expected to provide some social services and welfare programmes in addition to their normal economic activities (Hinson and Ndhlovu 2011). Firms balancing their economic and social goals would be able to achieve their business objectives and address 
societal concerns at the same time. This is what is termed strategic CSR (Lantos 2001; Porter and Kramer 2006).

A study of CSR practice and motivations in Spain, Prado-Lorenzo et al. (2008), after controlling for the size of the companies, found that disclosure of information on CSR leads to an improved corporate image which eventually increases the rate of sales growth. They state that firms which have disclosed a greater volume of information on CSR have experienced greater sales growth, as opposed to those organisations which have not disclosed information publicly (Prado-Lorenzo et al. 2008, p.1259). CSR has been found to be positively related to customer attraction and retention, as well as customer loyalty (Lee et al. 2011; Weber 2008). Similarly, loyal customers will result in firm growth due to their long stay with an organisation and their potential of attracting other users of products and services to the organisation. Customer attraction, retention and loyalty could be said to be positive enablers to firm growth.

P16: Corporate social responsibility is related to a firm growth.

The integration of $\mathrm{MO}$ and CSR is expected to result in firm growth as depicted by the model. This is expected to result in synergy, and thus translate into firm growth (Narver and Slater 1990; Maignan et al. 1999; Qu 2009; Pirithiviraj and Kajendra 2010; Brik et al. 2011; Arshad et al. 2012). The integration of MO and CSR as a competitive strategic tool is key to this study. An emerging logic in marketing is that, multiple approaches to strategy from both social and economic perspective is key to guarantee a certain level of business performance (Mahmoud 2016). Scholars' attention has been drawn to the fact that market orientation needs to be incorporated as a bundle into other strategic actions to achieve effective and efficient performance (Cano et al. 2004; Qu 2009; Brik et al. 2011; Hakala 2011; Mahmoud 2016). Mitchell et al. (2010) advocated for the incorporation of macro marketing variables such as corporate social responsibility, ecological and environmental issues as additional variables into future market orientation studies. Accordingly, we argue in this study that:

P17: Integration of MO and CSR is related to a firm growth.

\section{MO, CSR and employee commitment}

Employee commitment in this conceptualisation means the willingness of employees to go the extra mile to seek the collective interest of the organisation (Agarwal et al. 2003). Specifically, employee commitment means that people in an organisation are genuinely concerned about the needs and problems of each other (Glavas and Piderit 2009). They own the organisation and working for the organisation is reflective of being a part of "one big family". When employees are satisfied, they are emotionally attached to each other. In such organisations, employees view themselves as independent individuals who have to tolerate others around them. Employee commitment as an outcome variable has been employed in previous MO and CSR research (Agarwal et al. 2003).

Prior studies have indicated a relation between market orientation and employee commitment (Kohli and Jaworski 1990; Jaworski and Kohli 1993). A marketoriented culture facilitates clarity of focus and vision in an organisation. This generates pride in belonging to an organisation, and results in high employee morale and greater organisational commitment (Jaworski and Kohli 1993). Siguaw et al. (1994) report that, if a firm is perceived as having a high market orientation, then the sales force practice a greater level of customer orientation. Market orientation reduces role stress and engenders greater job satisfaction and organisational commitment. Additionally, it provides psychological and social benefits for employees. Market orientation leads to a sense of pride and belongingness in an organisation, in which all departments and individuals work towards the common goal of serving customers. If this objective is achieved, it results in employees sharing a feeling of worthwhile contribution, as well as higher levels of job satisfaction and commitment to the organisation (Kohli and Jaworski 1990). Thus,

\section{P18: Market orientation is related to employee} commitment.

Corporate social responsibility has a positive effect on attracting more talented employees, employee identification with the organisation and employee creative involvement (see Maignan et al. 1999; Greening and Turban 2000; Carmeli et al. 2007; Glavas and Piderit 2009). Smart employees might prefer to be associated with organisations that have friendly and good corporate social responsibility policies and programmes in place. Maignan et al. (1999) and McGuire et al. (1988) suggest that CSR activities stimulate a firm's ability to attract more talented and committed individuals who seek to merge their work and non-work lives and boost internal employee morale and commitment within the firm. CSR will improve employees' relations with the organisation in addition to its stakeholders (Akgeyik 2005; Glavas and Piderit 2009).

P19: Corporate social responsibility is related to employee commitment.

The integration of MO and CSR on organisational performance is operationalised in the framework yield employee commitment. This is expected to result in synergy, and thus translate into superior organisational performance (Narver and Slater 1990; Maignan et al. 1999; Qu 2009; Pirithiviraj and Kajendra 2010; Brik et al. 2011; Arshad et al. 2012). The integration of MO and CSR as a competitive strategic tool is important to this 
study. An emerging logic in marketing is that multiple approaches to strategy from both social and economic perspective is key to guarantee a certain level of business performance (Mahmoud 2016). Scholars' attention has been drawn to the fact that market orientation needs to be incorporated as a bundle into other strategic actions to achieve effective and efficient performance (Cano et al. 2004; Qu 2009; Brik et al. 2011; Hakala 2011; Mahmoud 2016). Mitchell et al. (2010) advocated for the incorporation of macro marketing variables such as corporate social responsibility, ecological and environmental issues as additional variables into future market orientation studies. Accordingly, we argue in this study that:

P20: Integration of MO and CSR is related to employee commitment.

\section{MO, CSR and service quality}

Service quality as an outcome variable has been employed in previous market orientation and corporate social responsibility studies (see Matear et al. 2004; Sen et al. 2006; Garcia de los Salmones et al. 2005). Service quality in this conceptualisation means that an organisation has superior service provision relative to its competitors. It also represents improvements in the quality of service delivery relative to the competition and customers' satisfaction with service quality levels of the organisation in question. In addition, compared to competitors, word of mouth testimonies regarding service quality from customers are excellent (Matear, et al. 2004). Firms with high service quality are those that have excellent service recovery strategies in their operations (Zebal and Godwin 2011). Another feature of an organisation with excellent service quality is that consumers have a positive perception of service quality of such organisations in relation to their competitors in the same industry (Garcia de los Salmones et al. 2005).

Service quality is the major driving force for business sustainability, and in today's competitive global marketplace, it is acknowledged to be essential for the success of the firm (Ismail et al. 2006). The primary objective of service providers and marketers is identical, which is to develop and provide services that satisfy customer needs and expectations. In the service industry, the goal of the service marketer is to close or narrow the gap between expectations and perceptions of customers (Ismail et al. 2006). In the marketing literature, service quality is a distinctive element that firms should strive for (Ismail et al. 2006).

Therefore, a key strategy for customer-focused firms is to measure service quality. Customer satisfaction or dissatisfaction may result from experiencing a service and comparing that experience with the kind of quality of service that was expected (Ismail et al. 2006; Voon 2006). According to Voon (2006), service is said to be the competitive tool for differentiation that is difficult for rivals to imitate, and service quality needs to be strategically managed for competitive advantage. The literature underscores the point that market-oriented service behaviors are instrumental in delivering quality service (Camarero 2007; Lam et al. 2012; Voon 2006). Market orientation could also lead to improved service quality for service industry organisations (Agarwal et al. 2003; Camarero 2007; Lam et al. 2012).

Camarero's (2007) study shows that the market-driven financial and insurance companies are more committed to meeting or exceeding their customers' expectations and as such, to providing premium service quality for their customers. Similarly, Gounaris et al. (2003) stated that in the banking sector the market-oriented service firm is capable of understanding and meeting the needs and desires of its target markets as far as creating added value for its customers and therefore, generating marked improvements in customer perception of service quality. An empirical investigation of the relationship between market orientation, service quality and business performance in retail stock brokerage firms in Taiwan was provided by Voon (2006), who empirically tested and validated a service-driven market orientation tool and generally supported the assertion that a higher degree of market orientation correlates with improved delivery of services. Thus far, it has been argued that strong market-oriented service providers are more likely to meet or exceed their customer needs and expectations with the provision of superior quality services. Lam et al. (2012) investigated the relationship between market orientation and service quality from a developing economy perspective and reported that market orientation is significantly related to service quality.

P21: Market orientation is related to service quality.

Studies have found a link between corporate social responsibility (CSR) initiatives and service quality (SQ). Body Shop has been used as an illustration. Its use of natural ingredients and environmentally friendly practices has had positive associations with consumer perceptions of its products (see Poolthong and Mandhachitara 2009). Sen and Bhattacharya (2001) found that consumers are sensitive to the implications of CSR activities as well as to the company's ability to exceed expectations. Garcia de los Salmones et al. (2005), for example, found that consumers' perception of CSR behaviour can have direct consequences for their assessment of the service and SQ. Furthermore, the levels of engagement in certain CSR activities in which customers expect their service providers to become engaged are proposed to influence SQ.

P22: Corporate social responsibility is related to service quality.

This conceptualisation assumed that the integration of MO and CSR should result in quality service delivery, which influences the overall efficiency of service firms' 
operations, and hence business performance. Consequently, the integration of MO and CSR on framework must lead to service quality delivery. Thus translate into superior service quality performance relative to the competition (Narver and Slater 1990; Maignan et al. 1999; Qu 2009; Pirithiviraj and Kajendra 2010; Brik et al. 2011; Arshad et al. 2012). The integration of MO and CSR as a competitive strategic tool is key to this study. An emerging logic in marketing is that multiple approaches to strategy from both social and economic perspective is key to guarantee a certain level of business performance (Mahmoud 2016). Scholars' attention has been drawn to the fact that market orientation needs to be incorporated as a bundle into other strategic actions to achieve effective and efficient performance (Cano et al. 2004; Qu 2009; Brik et al. 2011; Hakala 2011; Mahmoud 2016). Mitchell et al. (2010) advocated for the incorporation of macro marketing variables such as corporate social responsibility, ecological and environmental issues as additional variables into future market orientation studies. Accordingly, we argue in this study that:

P23: Integration of MO and CSR is related to service quality.

\section{MO, CSR and profitability}

From conceptual and empirical perspectives, market orientation has been proven to relate positively to firm profitability. Narver and Slater (1990) discovered that market orientation is an important determinant of profitability for both commodity and non-commodity businesses. Businesses with high market orientation tend to enjoy higher profitability than less market-oriented businesses. Slater and Narver (2000) found that market orientation is positively related to business profitability, measured by return on investment (ROI). Profitability is argued to be a consequence of market orientation (Kohli and Jaworski 1990; Narver and Slater 1990). Kohli and Jaworski (1990), in a field interview, discovered that profitability is a consequence of a market orientation rather than a part of it. Accordingly, we propose that:

P24: Market orientation is related to profitability.

Theoretically, it is argued that CSR has significant implications for a firm's financial performance (Lee 2008; Wang, Choi and Li 2008). CSR is vital for competitive success (Orlitzky et al. 2003). A good name can enhance business in good times and protect it during a crisis (Smith 2007). Smith (2007) argues that the prolonged advantage of corporate social responsibility ensures sustainable economic advantage and should be a long-term objective of any organisation. Orlitzky et al. (2003), in discussing the link between corporate social performance and financial performance, have shown that there is evidence suggesting that engaging in corporate social responsibility practices result in an increase in the overall profitability of firms. Conversely, Aupperle et al. (1985) did not find any relationship between corporate social responsibility and firm profitability. According to their findings, varying levels of corporate social responsibility activities did not correlate with firm performance. Scott (2007) is of the view that ccorporate profitability is a necessary condition for corporate responsibility. Similarly, corporate social responsibility can help companies succeed and increase their profitability and overall performance (Olowokudejo et al. 2011). Having discussed previous scholarly works on CSR and organisational performance, the section that follows is devoted to CSR studies in the service industry, especially studies in the banking sector.

Vogel (2005) notes that the new world of CSR emphasizes the link between CSR and corporate financial success. Confirmation for such emphasis, Vogel (2005) states, are the many works (e.g. Dickson 2004; Laszlo 2003; Scott and Rothman 1992; Waddock et al. 2002) that promote the 'responsibility-profitability connection 'and assert that CSR leads to long-term shareholder value. He also reports that 'according to a 2002 survey by PricewaterhouseCoopers, "70 percent of global chief executives believe that CSR is vital to their companies' profitability". This evidence suggests that CSR is evolving into a core business function which is central to the firm's overall strategy and vital to its success. Profitability in this conceptualisation refers to an improvement in a number of performance variables relative to competitors. These include total assets, deposits, advances, returnon-equity, net interest margins, cost-to-income ratio and asset quality (Jaworski and Kohli 1993; Orlitzky et al. 2003; Smith 2007). Profitability in a firm's assets base is a positive indication relative to the competitor.

P25: Corporate social responsibility is related to profitability.

The integration of MO and CSR on profitability is depicted in the model. The proposition here is that integrating economic and social strategies must result in profitable operations of firms. The integration of $\mathrm{MO}$ and CSR as a competitive strategic tool is key to this study. An emerging logic in marketing is that multiple approaches to strategy from both social and economic perspective is key to guarantee a certain level of business performance (Mahmoud 2016). Scholars' attention has been drawn to the fact that market orientation needs to be incorporated as a bundle into other strategic actions to achieve effective and efficient performance (Cano et al. 2004; Qu 2009; Brik et al. 2011; Hakala 2011; Mahmoud 2016). Mitchell et al. (2010) advocated for the incorporation of macro marketing variables such as corporate social responsibility, ecological and environmental issues as additional variables into future market orientation studies. Accordingly, we argue in this study that: 
P26: Integration of $M O$ and CSR is related to profitability.

\section{Control variables}

Narver and Slater (1990) show that the marketing strategy literature places considerable emphasis on eight situational variables that may affect business performance. The control variables are potential variables that are capable of influencing firm performance, rather than the identified variables. For instance, technology and organisational size are potential factors that can influence firm performance, other than MO and CSR. As with other studies in the strategic marketing literature, these situational variables are controlled in analyzing the effects of the interaction of market orientation and corporate social responsibility on business performance in this conceptualisation. The study posits that apart from the interactive effects of MO and CSR, there are other variables that can impact on an organisation's performance. The control variables considered in this study are broken into two main groups: market-related control variables and firm-level control variables (Narver and Slater 1990). Some of the market-related control variables considered in this study, as shown in the conceptual framework, are technology, the general economy, competitive intensity, and market turbulence and buyer power. The firm-level control variables include ownership, age, assets and size of the firm. With the components of the conceptual framework having been presented and explained above, the next section provides the discussions and managerial implications of the conceptualised model.

\section{Discussions and implications}

Prior researchers have largely not focused on how management factors, interdepartmental dynamics, and organisational systems impact on MO and CSR simultaneously (Aguinis and Glavas 2012). Aguinis and Glavas (2012) and Kuada and Hinson (2012) opined that the investigation into the predictors or antecedents on corporate social responsibility is scanty. This calls for scholars in marketing to research into the factors that can influence MO and CSR simultaneously in an organisational setting. In this competitive era firms cannot survive on a single strategy (Grinstein 2008; Brik et al. 2011; Mitchell et al. 2010; Blankson et al. 2013; Han et al. 2013). This phenomenon is encouraging firms to integrate economic and social strategies in contemporary times in the business environment. Drawing from resource-based perspectives both market orientation and corporate social responsibility have been viewed as corporate resources for business performance (Morgan et al. 2009). In this sense, in an industry where the level of market orientation and corporate social responsibility are low, firms that are marketoriented and socially responsible should experience high business performance than rival firms in such industries (Qu and Ennew 2007).

Managers' skills in initiating and implementing market orientation and corporate social responsibility initiatives could serve as intangible resources that propel the performance of their organisations. Moreover, if these initiatives are valued by the target market, as part of the conceptualisation theoretical contributions a model of significant factors determining market orientation and corporate social responsibility was developed. The unique feature of this model is the common predictors of both market orientation and corporate social responsibility in an organisation. This claim needs to be further interrogated by future researchers. For practitioners, these findings suggest that organisations ought to view corporate social responsibility and market orientation as a complementary strategic choice by managers rather than as two separate strategies that compete for organisational resources. These findings are particularly important in the context of a developing economy in which practitioners might be skeptical in implementing western theories in their businesses (Osuagwu 2006; Appiah-Adu 1998). This assertion is based on the assumption that CSR hitherto was regarded as incompatible with market strategies like market orientation developing economies because of the absence of strong institutional support for CSR and the presence of weak and ineffective laws to guard against unethical practices (Atuguba and Dowuona-Hammond 2008). Foo (2007) is of the view that CSR activities may put service firms at a competitive disadvantage vis-a-vis their competitors and as they might resist its adoption.

Also, implementation of firm market orientation and corporate social responsibility is a critical issue requiring much more attention from practitioners (Voola and O'Cass 2010). Management inaction in integrating economic and social strategy into the corporate strategy could be harmful to the competitiveness of service firms. Management knowledge about their target market perceptions regarding their economic, social, ethics, philanthropic, and environmental performance are important for firms in the marketplace (Jaworski and Kohli 1993: Carroll 1991). Inadequate knowledge is detrimental to firm operations. Corporate reputation is derived from stakeholders' perception of firm performance in the economic and social strategies they pursue. Affection for firms' products and services, as a result of it, is prudent economic and social strategies which then translate into more patronage for its services. In terms of social strategy, firms that are perceived to fulfill stakeholders' demands, for example, paying shareholders dividends, settling tax obligations to the central government, donating to the community in terms of their needs are in a better position of gaining competitive advantage over 
their rivals. Firms that do well economically, socially, ethically, and legally, are likely to enjoy profits in the long-run. Conceptually, firms are better of with high CSR and MO initiatives relative to low MO and CSR. It is important to note that, the level of economic and social strategies exhibited by firms will indicate where the firm will be in terms of these interventions and their relationship to performance (Porter and Kramer 2006; Qu 2009; Brik et al. 2011).

\section{Conclusions and direction for future research}

This conceptualisation has contributed to the limited studies in the scholarly literature on the integration of market orientation and corporate social responsibility (Qu 2009; Brik et al. 2011; Mahmoud and Hinson 2012a, b, Hinson and Mahmoud 2011). The study has conceptualised a theoretical link on the integration of MO, CSR and business performance. This framework could be applied by firms to enhance their business performance or competitiveness. The conceptualisation has also suggested predictor variables of corporate social responsibility similar to that of market orientation. These measures depart from the use of traditional measures of size, income, origin of firms and external pressure as factors of engagement in CSR activities (Kuada and Hinson 2012). This study offers an opportunity for appropriate strategic marketing development in the several industries and enables managers of these institutions to identify the appropriate blend of market orientation and corporate responsibility for superior business performance.

Haugland et al. (2007) encouraged researchers to elaborate on the role of market orientation and other strategic orientations. The literature on market orientation and corporate social responsibility in developing economies is now growing and therefore this conceptualisation will aid in building and enhancing the literature on predictors and integration of market orientation, corporate social responsibility and organisational performance.While this study supports the integration of market orientation and corporate social responsibility for superior business performance, other strategic variables might be appropriate than the two constructs proposed in the framework. This paper provides an opportunity for future inquiry into other variables.

Marketing scholars are recommended to explore further the integration of MO and CSR in both the private and public by adopting/adapting the conceptualised and the hypotheses presented in this study. This will best help inform policy direction for the businesses economic and social interventions. Either single-industry or multiple - industry study could be employed to maximise the generalisability of the integration of MO and CSR. The study provides an opportunity for further studies to consider examining the common factors driving market orientation and corporate social responsibility simultaneously in different industry settings. Changes in the market characteristics, our understanding of competitive behaviour and advances in management theory and conceptualization development can limit the applicability of the proposed conceptualization and hypotheses (Darroch, et. al 2004). Despite these shortcomings, it is the conviction of the researchers that the conceptualisation puts forward will stimulate a conversation among marketing scholars about the potential hazards of strategy myopia and the benefits of strategy integration for the marketing discipline (Davis et al. 2013).

\section{Acknowledgements \\ We will like to acknowledge the following institutions for their support in developing this manuscript. These are: \\ University of Ghana Business School. \\ University of Ghana Carnegie Next Generation of African Academics Project. BANGA Project, University of Ghana.}

\section{Authors' contributions}

Authors contributed equally to the development of this manuscript. All authors read and approved the final manuscript.

\section{Competing interest}

The authors declare that they have no competing interests.

\section{Publisher's Note}

Springer Nature remains neutral with regard to jurisdictional claims in published maps and institutional affiliations.

\section{Author details}

${ }^{1}$ Department of Marketing and Entrepreneurship, University of Ghana Business School, University of Ghana, Accra, Ghana. ${ }^{2}$ Department of Marketing and Logistics, University of North Texas, Denton, TX, USA.

Received: 26 July 2017 Accepted: 1 November 2017

Published online: 22 November 2017

\section{References}

Agarwal, S., Erramilli, M. K., \& Dev, C. S. (2003). Market orientation and performance in service firms: Role of innovation. Journal of Services Marketing, $17(1), 68-82$.

Aguinis, H., \& Glavas, A. (2012). What we know and don't know about corporate social responsibility a review and research agenda. Journal of Management, 38(4), 932-968.

Akgeyik, T. (2005). The human resource management dimensions of corporate social responsibility in Turkey: A survey. Journal of Academy of Business and Economics, 5(1), 25-32.

Anderson, E. W., Fornell, C., \& Mazvancheryl, S. K. (2004). Customer satisfaction and shareholder value. Journal of Marketing, 68(4), 172-185.

Appiah-Adu, K. (1998). Market orientation and performance: Empirical test in a transition economy. Journal of Strategic Marketing, 6(1), 25-45.

Arshad, R., Mansor, S. M., \& Othman, R. (2012). Market orientation, firm performance and the mediating effect of corporate social responsibility. Journal of Applied Business Research, 28(5), 851.

Atuahene-Gima, K. (2005). Resolving the capability-Rigidity paradox in new product innovation. Journal of Marketing, 69(4), 61-83.

Atuguba, R. A., \& Dowuona-Hammond, C. (2008). Corporate social responsibility in Ghana. The New Legon Observer: Ghana Society for Development Dialogue, 2(10), 15-20.

Aupperle, K. E., Carroll, A. B., \& Hatfield, J. D. (1985). An empirical examination of the relationship between corporate social responsibility performance and profitability. The Academy of Management Journal, 28, 446-463.

Avlonitis, G. J., \& Gounaris, S. P. (1999). Marketing orientation and its determinants: An empirical analysis. European Journal of Marketing, 33(11/12), 1003-1037. 
Backhaus, K., Stone, B., \& Heiner, K. (2002). Exploring the relationship between corporate social performance and employer attractiveness. Business and Society, 41(3), 292-319.

Blankson, C., Cowan, K., Crawford, J., Kalafatis, S., Singh, J., \& Coffie, S. (2013). A review of the relationship and impact of market orientation and market positioning on organisational performance. Journal of Strategic Marketing, 21(6), 499-512. https://doi.org/10.1080/0965254x.2013.804857.

Brammer, S., \& Millington, A. (2005). Corporate reputation and philanthropy: An empirical analysis. Journal of Business Ethics, 61, 29-44.

Brik, A. B., Rettab, B., \& Mellahi, K. (2011). Market orientation, corporate social responsibility, and business performance. Journal of Business Ethics, 99, 307-324.

Camarero, C. (2007). Relationship orientation or service quality?: What is the trigger of performance in financial and insurance services? International Journal of Bank Marketing, 25(6), 406-426.

Cano, C. R., Carrillat, F. A., \& Jaramillo, F. (2004). A meta-analysis of the relationship between market orientation and business performance: Evidence from five continents. International Journal of Research in Marketing, 21(2), 179-200.

Carmeli, A., Gilat, G., \& Waldman, D. A. (2007). The role of perceived organizational performance in organizational identification, adjustment and job performance. Journal of Management Studies, 44(6), 972-992.

Carroll, A. B. (1991). The pyramid of corporate social responsibility: Toward the moral management of organisational stakeholders. Business Horizons, 34, 39-48.

Carroll, A. B. (2000). Ethical challenges for business in the new millennium: Corporate social responsibility and models of management morality. Business Ethics Quarterly, 10(1), 33-42.

Cervera, A., Mollá, A., \& Sanchez, M. (2001). Antecedents and consequences of market orientation in public organisations. European Journal of Marketing, 35(11/12), 1259-1288.

Darroch, J., Miles, M. P., Jardine, A., \& Cooke, E. F. (2004). The 2004 AMA definition of marketing and its relationship to a market orientation: An extension of Cooke, Rayburn, \& Abercrombie (1992). Journal of Marketing Theory and Practice, 12(4), 29-38.

Davis, D. F., Golicic, S. L., Boerstler, C. N., Choi, S., \& Oh, H. (2013). Does marketing research suffer from method myopia? Journal of Business Research, 66, 1245-1250.

Dickson, M. (2004). Good, not great. Financial Times, 7, 20.

Dwairi, M., Bhuian, S., \& Jarkus, A. (2007). Revisiting the pioneering market orientation model in an emerging economy. European Journal of Marketing, 41(7/8), 713-721.

Ellis, P. D. (2006). Market orientation and performance: A meta-analysis and crossnational comparisons. Journal of Management Studies, 43(5), 1089-1107.

Felix, R. (2015). Market orientation plus: Antecedents and consequences of market orientation and corporate social responsibility in Mexico. Journal of Global Marketing, 28(3-5), 172-188.

Flavián, C., \& Lozano, J. (2006). Organisational antecedents of market orientation in the public university system. International Journal of Public Sector Management, 19(5), 447-467.

Foo, L. M. (2007). Stakeholder engagement in emerging economies: Considering the strategic benefits of stakeholder management in a cross-cultural and geopolitical context. Corporate Governance, 7(4), 379-387.

Fornell, C. (1992). A national customer service barometer: The Swedish experience. Journal of Marketing, 56, 1-21.

Fornell, C., Mithas, S., Morgenson, F. V., \& Krishnan, M. S. (2006). Customer satisfaction and stock prices: High returns, low risk. Journal of Marketing, 70, $1-14$.

Galbreath, J. (2010). Drivers of corporate social responsibility: The role of formal strategic planning and firm culture. British Journal of Management, 21(2), 511-525.

Garcia de los Salmones, M. G. M., Crespo, A. H., \& Del Bosque, I. R. (2005). Influence of corporate social responsibility on loyalty and valuation of services. Journal of Business Ethics, 61(4), 369-385.

Glavas, A., \& Piderit, S. K. (2009). How does doing good matter? Effects of corporate citizenship on employees. The Journal of Corporate Citizenship, 36(Winter), 51-70

Gounaris, S. P., Stathakopoulos, V., \& Athanassopoulos, A. D. (2003). Antecedents to perceived service quality: An exploratory study in the banking sector. International Journal of Bank Marketing, 21(4), 168-190.

Greening, D. W., \& Turban, D. B. (2000). Corporate social performance as a competitive advantage in attracting a quality workforce. Business and Society, 39, 254-280.

Greenley, G., Hooley, G., \& Reidd, J. (2005). Market in a multiple stakeholder orientation context: Implications for marketing capabilities and assets. Journal of Business Research, 58, 1483-1494.
Grinstein, A. (2008). The effect of market orientation and its components on innovation consequences: A meat-analysis. Journal of the Academy of Marketing Science, 36(2), 166-173.

Gruca, T. S., \& Rego, L. L. (2005). Customer satisfaction, cash flow, and shareholder value. Journal of Marketing, 69(3), 115-130.

Hakala, H. (2011). Strategic orientations in management literature: Three approaches to understanding the interaction between market, technology, entrepreneurial and learning orientations. International Journal of Management Reviews, 13(2), 199-217.

Han, X., Hansen, E., Panwar, R., Hamner, R., \& Orozco, N. (2013). Connecting market orientation, learning orientation and corporate social responsibility implementation: Is innovativeness a mediator? Scandinavian Journal of Forest Research, 28(8), 784-796.

Harris, L. C. (2000). The organisational barriers to developing market orientation. European Journal of Marketing, 34(5/6), 598-624.

Harris, L. C., \& Ogbonna, E. (2001). Strategic human resource management, market orientation, and organisational performance. Journal of Business Research, 51(2), 157-166.

Harris, L. C., \& Piercy, N. F. (1999). A contingency approach to market orientation: Distinguishing behaviours, systems, structures, strategies and performance characteristics. Journal of Marketing Management, 15(7), 617-646.

Haugland, S. A., Myrtveit, I., \& Nygaard, A. (2007). Market orientation and performance in the service industry: A data envelopment analysis. Journal of Business Research, 60(11), 1191-1197.

Hinson, R. (2006). Marketing of services: A managerial perspectives. Accra: Sedco Publishing Ltd..

Hinson, R. E., \& Mahmoud, M. A. (2011). Qualitative insights into market orientation in small Ghanaian businesses. International Journal of Marketing Studies, 3(1), 35.

Hinson, R. E., \& Ndhlovu, T. P. (2011). Conceptualising corporate social responsibility (CSR) and corporate social investment (CSI): The South African context. Social Responsibility Journal, 7(3), 332-346.

Hult, G. T. M., Ketchen, D. J., \& Slater, S. F. (2005). Market orientation and performance: An integration of disparate approaches. Strategic Management Journal, 26(12), 1173-1181.

Hunt, S. D., \& Morgan, R. M. (1995). The comparative advantage theory of competition. Journal of Marketing, 59(2), 1-15.

Ismail, I., Haron, H., Ibrahim, D. A., \& Isa, S. M. (2006). Service quality, client satisfaction and loyalty towards audit firms perceptions of Malaysian public listed companies. Managerial Auditing Journal, 21(7), 738-756.

Jaworski, B. J., \& Kohli, A. K. (1993). Market orientation: Antecedents and consequences. Journal of Marketing, 57(3), 53-70.

Kirca, A., Jayachandran, S., \& Bearden, W. (2005). Market orientation: A metaanalytic review and assessment of its antecedents and impact on performance. Journal of Marketing, 69(2), 24-41.

Kocak, A., Carsrud, A., \& Oflazoglu, S. (2017). Market, entrepreneurial, and technology orientations: Impact on innovation and firm performance. Management Decision, 55(2), 248-270.

Kohli, A., \& Jaworski, B. (1990). Market orientation: The construct, research propositions, and managerial implications. Journal of Marketing, 54(2), 1-18.

Kuada, J., \& Buatsi, S. N. (2005). Market orientation and management practices in Ghanaian firms: Revisiting the Jaworski and Kohli framework. Journal of International Marketing, 13(1), 58-88.

Kuada, J., \& Hinson, R. E. (2012). Corporate social responsibility (CSR) practices of foreign and local companies in Ghana. Thunderbird International Business Review, 54(4), 521-536.

Kwon, Y. C., \& Hu, M. Y. (2000). Market orientation among small Korean exporters. International Business Review, 9(1), 61-75.

Kyriakopolos, K., \& Moorman, C. (2004). Tradeoffs in marketing exploitation and exploration strategies: The overlooked role of market orientation. International Journal of Research in Marketing, 21(3), 219-240.

Lafferty, B. A., \& Hult, G. T. M. (2001). A synconceptualisation of contemporary market orientation perspectives. European Journal of Marketing, 35(1/2), 92109.

Lam, S., Lee, V., Ooi, K., \& Phusavat, K. (2012). A structural equation model of TQM, market orientation and service quality: Evidence from a developing nation. Managing Service Quality, 22(3), 281-309.

Lantos, G. P. (2001). The boundaries of strategic corporate social responsibility. Journal of Consumer Marketing, 18(7), 595-632.

Laszlo, C. (2003). The sustainable company: How to create lasting value through social and environmental performance. Washington: Island Press. 
Lee, M. P. (2008). A review of the theories of corporate social responsibility: Its evolutionary path and the road ahead. International Journal of Management Reviews, 10, 53-73.

Lee, S. M., Lim, S. B., \& Pathak, R. D. (2011). Culture and entrepreneurial orientation: A multicountry study. The International Entrepreneurship and Management Journal, 7(1), 1-15

Lukas, B. A., \& Ferrell, O. C. (2000). The effect of market orientation on product innovation. Journal of the Academy of Marketing Science, 28(2), 239-247.

Luo, X. (2007). Consumer negative voice and firm-idiosyncratic stock returns. Journal of Marketing, 71(3), 75-88.

Luo, X., \& Bhattacharya, C. B. (2006). Corporate social responsibility, customer satisfaction, and market value. Journal of Marketing, 70(4), 1-18.

Luo, X., \& Homburg, C. (2007). Neglected outcomes of customer satisfaction. Journal of Marketing, 71(2), 133-149.

Luo, X., Li, H., Zhang, J., \& Shim, J. P. (2010). Examining multi-dimensional trust and multi-faceted risk in initial acceptance of emerging technologies: An empirical study of mobile banking services. Decision Support Systems, 49(2), 222-234

Mahmoud, M. A. (2016). Sustainable market orientation: A competitive strategic tool in an emerging economy context. Journal of Strategic Marketing, 24(7), 635-654.

Mahmoud, M. A., \& Hinson, R. E. (2012a). Market orientation, innovation and corporate social responsibility practices in Ghana's telecommunication sector. Social Responsibility Journal, 8(3), 327-346.

Mahmoud, M. A., \& Hinson, R. E. (2012b). Market orientation in a developing economy public institution: Revisiting the Kohli and Jaworski's framework International Journal of Public Sector Management, 25(2), 88-102.

Mahmoud, M. A., Kastner, A., \& Yeboah, J. (2010). Antecedents, environmental moderators and consequences of market orientation: A study of pharmaceutical firms in Ghana. Journal of Medical Marketing, 10(3), 231-244.

Maignan, I., \& Ferrell, O. C. (2004). Corporate social responsibility and marketing: An integrative framework. Journal of the Academy of Marketing Science, 32(1), 3-19.

Maignan, I., Ferrell, O. C., \& Hult, G. T. M. (1999). Corporate citizenship: Cultural antecedents and business benefits. Journal of the Academy of Marketing Science, 27(4), 455-469.

Matear, S., Gray, B. J., \& Garrett, T. (2004). Market orientation, brand investment, new service development, market position and performance for service organisations. International Journal of Service Industry Management, 15(3), 284-301.

Matsuno, K., Mentzer, J. T., \& Rentz, J. O. (2000). A refinement and validation of the MARKOR scale. Journal of the Academy of Marketing Science, 28(4), 527-539.

McDonald, L. M., \& Hung Lai, C. (2011). Impact of corporate social responsibility initiatives on Taiwanese banking customers. International Journal of Bank Marketing, 29(1), 50-63.

McDonald, L. M., \& Rundle-Thiele, S. (2008). Corporate social responsibility and bank customer satisfaction: A research agenda. International Journal of Bank Marketing, 26(3), 170-182.

McGuire, J. B., Sundgren, A., \& Schneeweis, T. (1988). Corporate social responsibility and firm financial performance. The Academy of Management Journal, 31(4), 854-872.

Mitchell, R. W., Wooliscroft, B., \& Higham, J. (2010). Sustainable market orientation: A new approach to managing marketing strategy. Journal of Macromarketing, 30(2), 160-170.

Mohr, J. J., \& Sarin, S. (2009). Drucker's insights on market orientation and innovation: Implications for emerging areas in high-technology marketing. Journal of the Academy of Marketing Science, 37(1), 85-96.

Morgan, N. A., Vorhies, D. W., \& Mason, C. H. (2009). Market orientation, marketing capabilities, and firm performance. Strategic Management Journal, 30(8), 909-920.

Morgan, R. E., \& Strong, C. A. (1998). Market orientation and dimensions of strategic orientation. European Journal of Marketing, 32(11/12), 1051-1073.

Narver, J., \& Slater, S. (1990). The effect of market orientation on business profitability. Journal of Marketing, 54(4), 20-35.

Olowokudejo, F., Aduloju, S. A., \& Oke, S. A. (2011). Corporate social responsibility and organisational effectiveness of insurance companies in Nigeria. Journal of Risk Finance, 12(3), 156-167.

Opoku, R. A., \& Essien, V. B. (2011). Employee perceptions of market orientation in the banking sector: A case from a developing country. Journal of Financial Services Marketing, 16(2), 139-152.

Orlitzky, M., Schmidt, F. L., \& Rynes, S. L. (2003). Corporate social and financial performance: A meta-analysis. Organisgelation Studies, 24, 403-441.

Osuagwu, L. (2006). Market orientation in Nigerian companies. Marketing Intelligence \& Planning, 24(6), 608-631.
Peloza, J. (2009). The challenge of measuring financial impacts from investments in corporate social performance. Journal of Management, 35(6), 1518-1541.

Peterson, D. K. (2004). The relationship between perceptions of corporate citizenship and organizational commitment. Business and Society, 43(3), 296-319.

Pirithiviraj, J. C. D., \& Kajendra, K. (2010). Relationship between market orientation and Corpoarte social responsibility with special reference to Sri Lankan financial sector. Journal of Emerging Trends in Economics and Management Sciences, 1(2), 107-113.

Poolthong, Y., \& Mandhachitara, R. (2009). Customer expectations of CSR, perceived service quality and brand effect in Thai retail banking. International Journal of Bank Marketing, 27(6), 408-427.

Porter, M. E., \& Kramer, M. R. (2006). Strategy and society. Harvard Business Review, 84(12), 78-92.

Porter, M. E., \& Kramer, M. R. (2011). Creating shared value. Harvard Business Review, 89(1/2), 62-77.

Prado-Lorenzo, J. M., Gallego-Álvarez, I., García-Sánchez, I. M., \& RodríguezDomínguez, L. (2008). Social responsibility in Spain: Practices and motivations in firms. Management Decision, 46(8), 1247-1271.

Pulendran, S., Speed, R., \& Widing, R. E. (2000). The antecedents and consequences of market orientation in Australia. Australian Journal of Management, 25(2), 119-143.

Qu, R. (2009). The impact of market orientation and corporate social responsibility on firm performance: Evidence from China. Asia Pacific Journal of Marketing and Logistics, 21(4), 570-582.

Qu, R., \& Ennew, C. (2007). The moderating effects of business environment on firms' development of market orientation. Journal of Strategic Marketing, 15(2), 121-138.

Quazi, A., \& Richardson, A. (2012). Sources of variation in linking corporate social responsibility and financial performance. Social Responsibility Journal, 8(2), 242-256.

Schwartz, M. S., \& Carroll, A. B. (2003). Corporate social responsibility: A threedomain approach. Business Ethics Quarterly, 13(04), 503-530.

Scott, M., \& Rothman, H. (1992). Companies with a conscience: Intimate portraits of twelve firms that make a difference. New York, NY: Citadel.

Scott, S. (2007). Corporate social responsibility and the fetter of profitability. Social Responsibility Journal, 3(4), 31-39.

Sen, S., \& Bhattacharya, C. (2001). Does doing good always lead to doing better? Consumer reactions to corporate social responsibility. Journal of Marketing Research, 38(2), 225-243.

Sen, S., Bhattacharya, C. B., \& Korshun, D. (2006). The role of corporate social responsibility in strengthening multiple stakeholder relationships: A field experiment. Journal of the Academy of Marketing Science, 34, 158-166.

Senthikumar, N., Ananth, A., \& Arulraj, A. (2011). Impact of corporate social responsibility on customer satisfaction in banking service. African Journal of Business Management, 5(7), 3028-3039.

Siguaw, J. A., Brown, G., Widing, I. I., \& Robert, E. (1994). The influence of the market orientation of the firm on sales force behaviour and attitudes. Journal of Marketing Research (JMR), 31(1), 106-116.

Singh, S., \& Ranchhod, A. (2004). Market orientation and customer satisfaction: Evidence from British machine tool industry. Industrial Marketing Management, 33, 135-144

Slater, S. F., \& Narver, J. C. (1994). Does competitive environment moderate the market orientation performance relationship? Journal of Marketing, 58, 46-55.

Slater, S. F., \& Narver, J. C. (2000). The positive effect of a market orientation on business profitability: A balanced replication. Journal of Business Research 48(1), 69-73.

Smith, A. D. (2007). Making the case for the competitive advantage of corporate social responsibility. Business Strategy Series, 8(3), 186-195.

Svendsen, A. C., Boutilier, R. G., \& Abbott, R. M. \& Wheeler, D. (2001). Measuring the business value of stakeholder relationships (part one). Centre for Innovation in Management, Simon Fraser University, Vancouver, BC (available at www.cica.ca).

Vogel, D.J. (2005). Is there a market for virtue? The business case for corporate social responsibility. California Management Review, 47, pp. 19-45.

Voola, R., \& O'Cass, A. (2010). Implementing competitive strategies: The role of responsive and proactive market orientation. European Journal of Marketing, $44(1 / 2), 245-266$.

Voon, B. H. (2006). Linking a service-driven market orientation to service quality. Managing Service Quality, 16(6), 595-619.

Waddock, S. A., Bodwell, C., \& Graves, S. B. (2002). Responsibility: The new business imperative. The Academy of Management Executive, 16(2), 132-148. 
Wang, H., Choi, J., \& Li, J. (2008). Too little or too much? Untangling the relationship between corporate philanthropy and firm financial performance. Organization Science, 19(1), 143-159.

Weber, M. (2008). The business case for corporate social responsibility: A company-level measurement approach for CSR. European Management Journal, 26(4), 247-261.

Webster, F. E. (1988). The rediscovery of the marketing concept. Business Horizons, 31(3), 29-39.

Whitehouse, L. (2006). Corporate social responsibility: Views from the frontline. Journal of Business Ethics, 63(3), 279-296.

Yan, J., Yan, J., Wang, L., Wang, L., Xiong, J., \& Xiong, J. (2017). Alcatel-Lucent falls, Huawei ascends: New product development makes the difference. Journal of Business Strategies, 38(1), 22-30.

Zebal, M. A., \& Godwin, D. R. (2011). Market orientation in a developing nationantecedents, consequences and the moderating effect of environmental factors. Marketing Bulletin, 22(1), 1-23.

Zeithaml, V. A. (2000). Service quality, profitability, and the economic worth of customers: What we know and what we need to learn. Journal of the Academy of Marketing Science, 28(1), 67-85.

Zhou, K. Z., Gao, G. Y., Yang, Z., \& Zhou, N. (2005). Developing strategic orientation in China: Antecedents and consequences of market and innovation orientations. Journal of Business Research, 58(8), 1049-1058.

\section{Submit your manuscript to a SpringerOpen ${ }^{\odot}$ journal and benefit from:}

- Convenient online submission

- Rigorous peer review

- Open access: articles freely available online

- High visibility within the field

- Retaining the copyright to your article

Submit your next manuscript at $\gg$ springeropen.com 